\title{
Analysis of Factors Affecting the Competitiveness of Indonesian Crude Palm Oil (CPO) Export in the Global Market
}

\author{
Mirawati Yanita , Dompak MT Napitupulu, dan Karina Rahmah
}

Faculty of Agriculture, University of Jambi, Indonesia

\begin{abstract}
This study aims to: (1) Analyze the development of Indonesian CPO export competitiveness in the global market from 1998 to 2017 (2) Analyze factors affecting the competitiveness of Indonesian CPO export in the global market from 1998 to 2017. The data used is time series spanning 20 years (1998-2017). The competitiveness of Indonesian CPO export in the global market is presented descriptively in the form of images, while affecting factors are analyzed using a multiple linear regression model. The results show that Indonesian CPO has comparative and competitive competitiveness in the global market. The results of multiple linear regression tests indicate that the factors that comparatively affect the competitiveness of Indonesian CPO exports in the global market are domestic $\mathrm{CPO}$ production, global $\mathrm{CPO}$ prices and petroleum prices while factors that competitively affect competitiveness are oil palm plantation area, Malaysian export volume, soybean oil price and exchange rates. Factors that positively impact Indonesian CPO competitiveness are domestic CPO production, oil prices and the oil palm plantation area. Improving these variables will increase the competitiveness of Indonesian CPO exports, while an increase in global CPO prices, soybean oil prices and the exchange rate will reduce the competitiveness of CPO exports. The variable that has no significant effect is the export volume of Malaysia.
\end{abstract}

Keywords: Crude Palm Oil (CPO), competitiveness, comparative, competitive, global market

Received 20 November 2019 | Revised 04 December 2019 | Accepted 03 January 2020

\section{Introduction}

Trade is a process of economic activity that plays an important role in many situations. When carried out between regions and countries, trade can improve the living standards and prosperity for said country. Global trade can be defined as trade between or across countries, which include exports and imports [1]. Indonesia is an agricultural country in which its economy is sustained by the agricultural sector. This can be observed through the increase in the Gross Domestic Product (GDP) of the agricultural sector. Based on the performance of the Indonesian economy, the agricultural sector has increased from IDR 1,129,053 billion in 2014 to IDR $1,307,026$ billion in 2018 [2].

\footnotetext{
*Corresponding author at: Faculty of Agriculture, University of Jambi, Jl. Raya Jambi - Muara Bulian Km 15,

Mendalo Darat, Jambi, 36361, Indonesia

E-mail address: mirawatiyanita@unja.ac.id
} 
One of the agricultural sub-sectors that significantly contribute to Indonesian economy is plantation. The plantation commodity that produces the largest amount of foreign exchange is palm oil which is exported in the form of crude palm oil (CPO). Palm oil is also an important element for a number of food and cosmetic products, in addition regarded as the cheapest source of vegetable oil in the international market [3] [4]. This condition is one of the causes of the rapid development of oil palm plantations in the tropics, especially Southeast Asia. Since 2009, Indonesia has become the largest producer of palm oil in the world [5] [4]. From 2010 to 2014, Indonesia was the largest $\mathrm{CPO}$ producing country in the world with an average contribution of $48.44 \%$ of the global CPO production [6].

Indonesia is the largest exporter of palm oil in the world, followed by Malaysia, the Netherlands and Papua New Guinea. Indonesia contributes an average of $46.12 \%$ of the global palm oil export. The average volume of the Indonesian palm oil export is 24.01 million tons per year [7].

Indonesian palm oil is expected to be able to continuously increase foreign exchange for the country and provide jobs, especially for communities surrounding palm oil production activities. Therefore, it is important to analyze Indonesian CPO competitiveness in the global market. The Indonesian CPO export competitiveness can be influenced by the area of palm oil, domestic $\mathrm{CPO}$ production, the export volume of competing countries (Malaysia), global CPO prices, substitute goods prices (soybean oil), petroleum prices and exchange rates.

Based on the background and the problems encountered, this study aims to: 1) analyze the development of Indonesian CPO export competitiveness in the global market from 1998 to 2017 and 2) analyze the factors affecting the competitiveness of Indonesian CPO exports in the global market from 1998 to 2017.

\section{Research Methods}

This research uses secondary data. The scope and limitations of this study encompasses Indonesian CPO export value, total Indonesian export value, global CPO export value, global export value, palm oil plantation area, domestic CPO production, competitor export value (Malaysia), international CPO prices, substitute goods prices (soybean oil), petroleum prices and exchange rates. The analyzed object was a CPO commodity coded HS 151110 through a time span of 20 years (1998-2017). This study uses descriptive analysis and quantitative analysis methods. The quantitative method used is the Revealed Comparative Advantage (RCA) approach, Export Competitiveness Index (ECI), and multiple linear regression analysis to analyze the factors that affect Indonesian CPO export competitiveness in the global market.

The Revealed Comparative Advantage (RCA) method is one of the methods used to analyze comparative and dynamic forms of competitiveness. The measured variable is the ratio of 
country i CPO export value to country i total export value which is then compared with the global CPO export value to global export value. The RCA can be formulated as follows [1]:

$$
R C A=\frac{X_{i j} / X_{t}}{W_{i j} / W_{t}}
$$

where:

$X_{i j} \quad=$ Value of Indonesian CPO export to the world (USD)

$X_{t} \quad=$ Total value of Indonesian exports to the world (USD)

$W_{i j} \quad=$ Global $\mathrm{CPO}$ export value (USD)

$W_{t} \quad=$ Global export value (USD)

If the RCA value of a country is greater than one, its commodities are highly competitive. Conversely, if the value of the RCA is smaller than one, its commodities are not competitive.

To measure the competitive advantage of Indonesian CPO commodities in the global market, the Export Competitiveness Index (ECI) method is used. The ECI value shows the competitiveness trends faced by one country against another country for a certain commodity. This value indicates whether a product in question has the ability to compete with other countries or not.

This tool compares the export ratio of a country for certain commodities in a certain period (t) with the export ratio of a country for certain commodities in the previous period $(t-1)$. ECI can be formulated as follows [1]:

$$
E C I=\frac{\left(\mathrm{X}_{\mathrm{ij}} / \mathrm{X}_{\mathrm{j}}\right)_{t}}{\left(\mathrm{X}_{\mathrm{ij}} / \mathrm{X}_{\mathrm{j}}\right)_{t-1}}
$$

where:

$$
\begin{array}{ll}
X_{i j} & =\text { Indonesian CPO export value in year } \mathrm{j} \text { (USD) } \\
X_{j} & =\text { global CPO export value in year } \mathrm{j} \text { (USD) } \\
\mathrm{T} & =\text { current period }(1998-2017) \\
(t-1) & =\text { previous period }(1998-2017)
\end{array}
$$

If the ECI value of a commodity is greater than one, the commodity faces an increasing trend in competitiveness. Conversely, if the ECI value is smaller than one, the commodity faces a declining trend in competitiveness. It can be concluded that in order to be able to compete and 
survive in the global market, a commodity should have a comparative and competitive index greater than one.

Based on the results of an empirical study, it was found that the variables that influence comparative competitiveness of Indonesia's CPO exports are domestic CPO production, international CPO prices and petroleum prices. While the variables that influence competitively are the area of palm oil, the volume of exports of competitors (Malaysia), soybean oil prices and the exchange rate. To answer the second objective, a multiple linear regression with Ordinary Least Square (OLS) method is used to analyze the factors that affect the competitiveness of Indonesian CPO export in the global market. Multiple linear regression is formulated by including variables which are assumed to be statistically affected by the competitiveness of Indonesian CPO exports in the global market. Comparative competitiveness (RCA) is assumed to be influenced by several variables, namely domestic CPO production, global CPO prices and petroleum prices which can be formulated with the following model:

$$
\mathrm{C}_{1}=\mathrm{b}_{0}+\mathrm{b}_{2} \mathrm{X}_{2}+\mathrm{b}_{4} \mathrm{X}_{4}+\mathrm{b}_{6} \mathrm{X}_{6}+e
$$

$\mathrm{b}_{2}, \mathrm{~b}_{4}, \mathrm{~b}_{6}>0$

where:

$$
\begin{array}{ll}
C_{1} & =\text { Revealed Comparative Advantage } \\
X_{2} & =\text { Domestic CPO Production (Ton/year) } \\
X_{4} & =\text { Global CPO price (USD/Ton) } \\
X_{6} & =\text { Petroleum price (USD/Barrel) } \\
e & =\text { Error standard } \\
b_{0} & =\text { Constant } \\
b_{1} \ldots b_{n} & =\text { Estimation Coefficient }
\end{array}
$$

Competitive advantage (ECI) is influenced by a number of variables, namely palm oil plantation area, Malaysian export volume, soybean oil prices and exchange rates that can be formulated with the following model:

$$
\mathrm{C}_{2}=\mathrm{b}_{0}+\mathrm{b}_{1} \mathrm{X}_{1}+\mathrm{b} 3 \mathrm{X}_{3}+\mathrm{b}_{5} \mathrm{X}_{5}+\mathrm{b}_{7} \mathrm{X}_{7}+e
$$

$\mathrm{b} 1, \mathrm{~b} 5>0$

b3, b7, >0 
where:

$$
\begin{array}{ll}
C_{2} & =\text { Export Competitiveness Index } \\
X_{1} & =\text { Oil palm plantation area }(\mathrm{Ha}) \\
X_{3} & =\text { Export volume of competing country - Malaysia (Ton/Year) } \\
X_{5} & =\text { Price of soybean oil (USD/Ton) } \\
X_{7} & =\text { Exchange rate (/USD) } \\
e & =\text { Error standard } \\
b_{0} & =\text { Constant } \\
b_{1} \ldots b_{n}= & \text { Estimation Coefficient }
\end{array}
$$

\section{Results and Discussion}

\subsection{Development of Indonesian CPO Export in the Global Market}

The development of Indonesian CPO export volume in 1998-2017 tended to show a fluctuating increase, having an average growth of $10.58 \%$ per year. More details on the development of the volume and value of Indonesian CPO exports can be seen in the following figure.

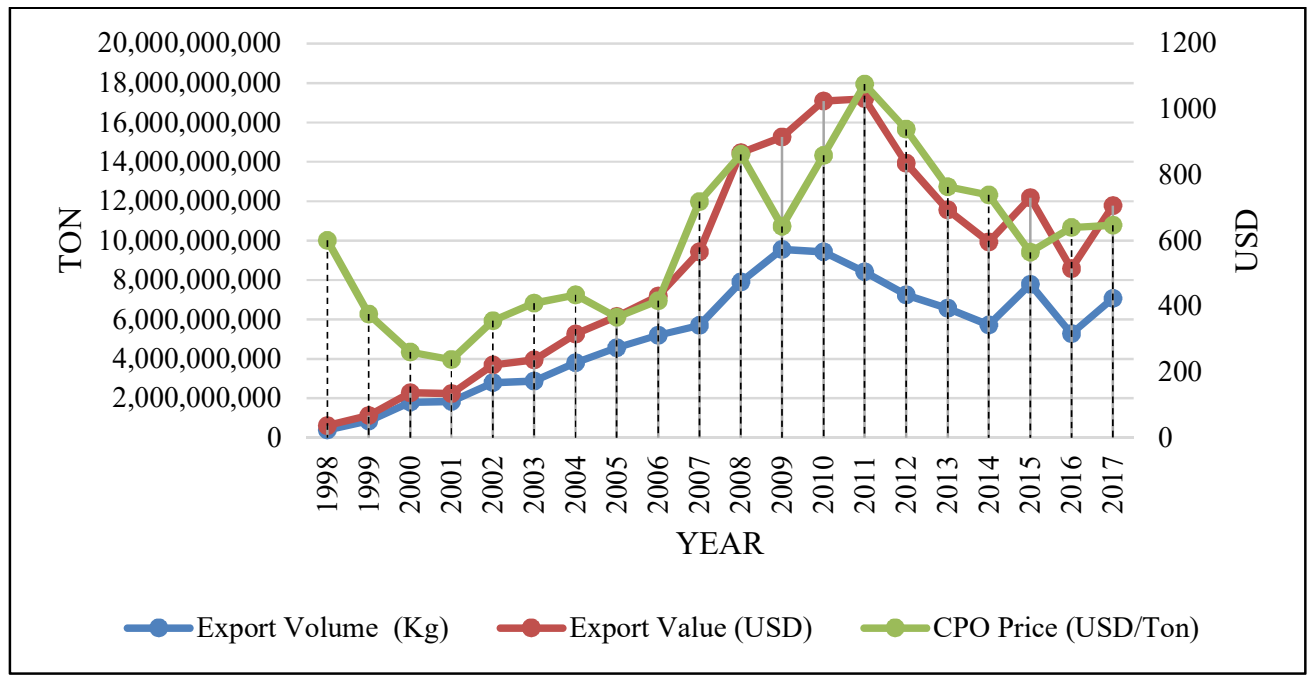

Source: UNCOMTRADE, 2019 (processed) [8]

Figure 1. Development of Indonesian CPO Export Volume and Value in 1998-2017

The export volume experienced a significant increase from 1998 to 2006 with an average increase of $10.58 \%$, per year, which is followed by an increase in export value. From the picture above, it can be seen that export value increased by $546.42 \%$ from 1998 to 2006 . The export volume decreased by $3 \%$ in 2010 , totaling at $16,291,856$ tons. However, the export value 
continued to increase until 2012, reaching 17,602,168,017 USD. In 2011, Indonesian CPO export volume increased until 2015, decreased by 14\% in 2016 and increased again to $27,353,339$ tons in 2017. The fluctuations in export volume are in line with the fluctuations in export value.

It can be seen from the figure 1, that the value of exports from 1998 to 2009 increased by $95.78 \%$. The volume of exports experienced a decline in 2010 to 2017 with an average of $6.29 \%$, the value of exports tends to fluctuate and decline until 2017 with an average of $14 \%$. The rise and fall of export volumes is in line with the rise and fall of export values.

\subsection{CPO Export Competitiveness}

\subsubsection{Comparative Advantage (RCA)}

The comparative advantage of CPO commodities in global markets can be analyzed using Revealed Comparative Advantage (RCA). Detailed results of the RCA analysis of Indonesian coffee can be seen in Figure 2 below.

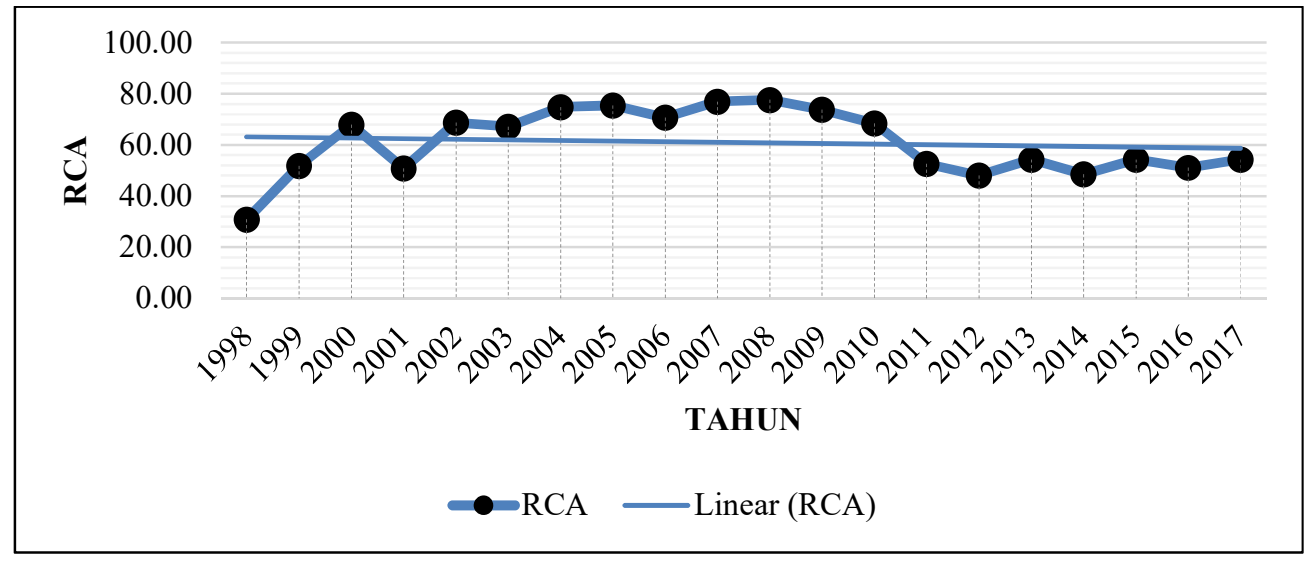

Source: UNCOMTRADE (processed) [8]

Figure 2. Trends in Indonesian CPO RCA in the Global Market

Figure 2 shows that from 1998 to 2017, Indonesian CPO has a comparative advantage as a whole in the global market since the value of Indonesian CPO RCA is greater than one with an average of 60.93 for a period of twenty years. This means that statistically, the comparative competitiveness of Indonesian CPO export in the global market shows an average value of greater than one through RCA. This is in accordance with research conducted by [9] on the Analysis of Indonesian Crude Palm Oil (CPO) Competitiveness in the Global Market which states that the calculation of its RCA index during the 1999-2014 period is greater than 1, specifically 66.12, showing that Indonesian CPO has comparative competitiveness in the global market. 


\subsubsection{Competitive Advantage (ECI)}

In this study, the Export Competitiveness Index analysis is used to determine whether or not Indonesia has a competitive advantage and competitiveness towards coffee commodities. Details can be seen in Figure 3 below.

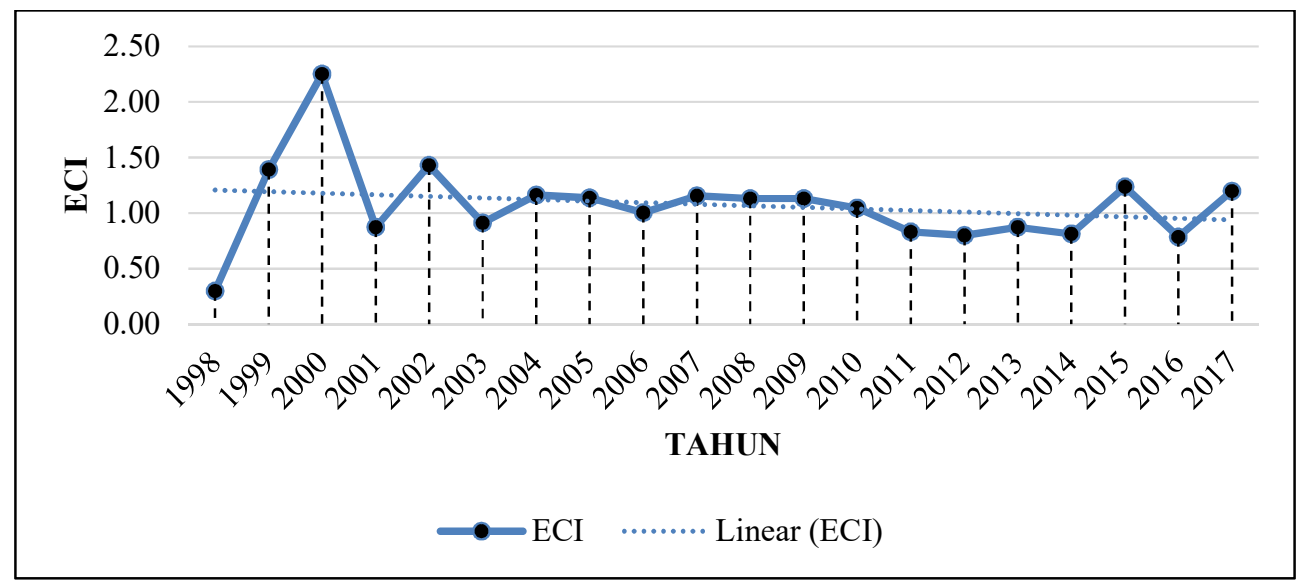

Source: UNCOMTRADE (processed) [8]

Figure 3. Trends in Indonesian CPO ECI in the Global Market

Figure 3 shows that the increase in the ECI value is very slow, meaning that the Indonesian $\mathrm{CPO}$ export competitiveness is at a vulnerable and weak point. The low competitiveness of Indonesian CPO export in the global market is caused by several factors, including the low value of Indonesian HS 151110 CPO export.

\subsubsection{Factors Affecting Indonesian CPO Export Competitiveness in Global Markets}

Based on trial and error, it was found that the variables that affect comparative competitiveness of Indonesian CPO exports are domestic CPO production, global CPO prices and petroleum prices. At the same time, the variables that influence competitively are the area of palm oil, the volume of exports of competitors (Malaysia), soybean oil prices and the exchange rate. Based on multiple linear regression analysis using the Ordinary Least Square (OLS) method, the following results are obtained.

\subsubsection{Comparative Estimation of Indonesian CPO Export Competitiveness in the Global Market (RCA)}

It is known that the dependent variable (Y) is Revealed Comparative Advantage (RCA) and the independent variable $(\mathrm{X})$ is factors that influence the comparative fluctuation of Indonesian $\mathrm{CPO}$ export competitiveness in the global market. Variable $\mathrm{X}$ consists of domestic CPO production (X2), global CPO price (X4) and petroleum price (X6). Analysis was conducted using multiple linear regression using statistical tools. The level of significance used was $95 \%$. Data processing of time series from 1998 to 2017 showed the following regression results. 
Table 1. Estimates of Factors Affecting Comparative Competitiveness of Indonesian CPO Exports in the Global Market

\begin{tabular}{lcccc}
\hline \multicolumn{1}{c}{ Variable } & Coefficient & Std. Error & t-Statistic & Prob. \\
\hline \multicolumn{1}{c}{ C } & 7.220509 & 1.735443 & 4.160613 & 0.0007 \\
X2 & -0.137767 & 0.130822 & -1.053084 & 0.3079 \\
X4 & -0.380547 & 0.154813 & -2.458106 & 0.0258 \\
X6 & 0.398719 & 0.124273 & 3.208407 & 0.0055 \\
\hline R-squared & 0.432124 & & & \\
Adjusted R-squared & 0.325648 & & & \\
S.E. of regression & 0.190210 & & & \\
Sum squared resid & 0.578875 & & & \\
Log likelihood & 7.045239 & & & \\
F-statistic & 4.058394 & & & \\
Prob(F-statistic) & 0.025370 & & & \\
Mean dependent var & 4.086035 & & & \\
S.D. dependent var & 0.231627 & & & \\
Akaike info criterion & -0.304524 & & & \\
Schwarz criterion & -0.105377 & & & \\
Hannan-Quinn criter. & -0.265648 & & & \\
Durbin-Watson stat & 1.063793 & & & \\
\hline Soure: Processed Resits & & & \\
\hline
\end{tabular}

Source: Processed Results using Eviews9

Based on the results above, the comparative competitiveness of Indonesian CPO exports in the global market can be shown as follows:

$\mathrm{RCA}=7.220509-0.137767 \mathrm{X} 2-0.380547 \mathrm{X} 4+0.398719 \mathrm{X} 6$

The results showed a determinant coefficient $\left(\mathrm{R}^{2}\right)$ of 0.43 , meaning that the variation of independent variables namely domestic $\mathrm{CPO}$ production, global $\mathrm{CPO}$ prices and petroleum prices were only able to clarify the dependent variable namely the competitiveness of Indonesian $\mathrm{CPO}$ export in the global market by $43 \%$ while the remaining $57 \%$ is clarified by other factors outside the model.

Factors that affect the competitiveness of Indonesian $\mathrm{CPO}$ export in the global market can be simultaneously shown using the $\mathrm{F}$ test. The results of the simultaneous test (F-test) showed a value of 29.85 greater than the F-table $\alpha=0.05$ (3.20) or $F_{\text {hit }}(29.85)>F_{\text {table }}$ (3.20) with a probability of 0.000001 . This means that the independent variables, namely domestic CPO production, global CPO prices and petroleum prices simultaneously influence the dependent variable, namely the competitiveness of Indonesian CPO exports on the global market comparatively $\left(\mathrm{R}^{2}>0\right)$. Factors partially affecting the competitiveness of Indonesian CPO export in the global market can be determined by observing the probability value of each export competitiveness variable. A probability value smaller than alpha (0.05) show different results at a $95 \%$ confidence level. Based on the results of the above analysis, it can be stated that domestic $\mathrm{CPO}$ production, global $\mathrm{CPO}$ prices and petroleum prices have a real partial impact on the competitiveness of the Indonesian CPO export in the global market. While domestic CPO production has no significant effect. 
Details of domestic CPO production $\left(\mathrm{X}_{2}\right)$, global CPO prices $\left(\mathrm{X}_{4}\right)$ and the price of petroleum $\left(\mathrm{X}_{6}\right)$ can be seen in the interpretation or description as follows:

\subsubsection{Effects of Domestic CPO Production $\left(\mathrm{X}_{2}\right)$ on the Indonesian CPO Export Comparative Competitiveness in the Global Market}

Based on the results of the multiple linear regression test, it can be determined that the domestic CPO production variable $\left(\mathrm{X}_{2}\right)$ has a coefficient of -0.137767 with a probability of 0.3079 . This means that domestic $\mathrm{CPO}$ production has a real positive value of $5 \%$ towards the comparative competitiveness of Indonesian CPO export in the global market, in which each increase in domestic CPO production of 1 ton will increase the competitiveness of Indonesian CPO export in the global market by 0.137767 , assuming other factors are considered permanent (ceteris paribus).

This research is supported by a previous research conducted by [10] who conducted research on the Effects of Total Production, International Prices, Exchange Rates and Interest Rates on the Competitiveness of Indonesian Palm Oil Exports (Study in 2009 - 2013). The results showed that the production of palm oil has a negative effect on Indonesian palm oil exports, thus it can be concluded that if production has increased, the level of export competitiveness has decreased. This can occur due to several factors, namely regulatory factors, domestic consumption factors, export marketing, and the quality of export commodity products respectively.

\subsubsection{Effects of Global CPO Price $\left(X_{4}\right)$ on the Comparative Competitiveness of the Indonesian CPO Export in the Global Market}

The global CPO price $\left(\mathrm{X}_{4}\right)$ has a coefficient of -0.380547 with a probability of 0.0258 . This means that the global CPO price has a negative effect on the competitiveness of Indonesian CPO export in the global market, in which every increase in global CPO price of 1 USD will reduce the competitiveness of Indonesian CPO export in the global market by 0.380547 , assuming other factors are considered constant (ceteris paribus). This contradicts the research of [11], which shows that the global palm oil price has a significant positive effect on palm oil exports both in the long and short terms. This contradiction occurs due to internal factors of the CPO itself such as the low quality of Indonesian CPO. Furthermore, it is also affected by the slow response of price changes on the global market and other factors such as import tariff policies and black campaigns.

\subsubsection{Effects of Petroleum Prices $\left(X_{6}\right)$ on the Comparative Competitiveness of the Indonesian CPO Export in the Global Market}

Petroleum prices $\left(\mathrm{X}_{6}\right)$ have a coefficient of 0.398719 with a probability of 0.0055 . This means that the price of petroleum has a positive effect on the competitiveness of Indonesian CPO export in the global market, in which every increase in the price of petroleum by 1 USD will increase the competitiveness of Indonesian CPO export on the global market by 0.398719 , 
assuming other factors are considered constant (ceteris paribus). The results of this study are in line with the economic theory which states that as the price of substitute goods increases, the demand for such goods will increase. This will ultimately increase the competitiveness of the Indonesian CPO export. In addition, this study was supported by [12] through a research on Analysis of Competitiveness and Factors Affecting the Indonesian CPO Export to China, Malaysia, and Singapore in the ASEAN-China Free Trade Agreement Scheme. The results showed that global oil prices significantly affected Indonesian CPO export to China, Malaysia and Singapore.

\subsubsection{Estimated Competitiveness Results of the Indonesian CPO Export in the Competitive Global Market (ECI)}

The dependent variable (Y) is the Export Competitiveness Index (ECI) and the independent variable $(\mathrm{X})$ is factors that competitively affect the competitiveness of Indonesian CPO export competitiveness in the global market. Variable $\mathrm{X}$ consists of the Indonesian palm oil plantation area $\left(\mathrm{X}_{1}\right)$, the export volume of competing countries (Malaysia) $\left(\mathrm{X}_{3}\right)$, soybean oil prices $\left(\mathrm{X}_{5}\right)$ and the exchange rate $\left(\mathrm{X}_{7}\right)$. Analysis was performed using multiple linear regression using statistical tools. The level of significance used was $95 \%$. This study hypothesized that the Indonesian palm oil plantation area, the export volume of competing countries (Malaysia), soybean oil prices and the exchange rate area factors that cause fluctuations in the competitiveness of Indonesian CPO export in the global market. Data processing of a time series from 1998 to 2017 showed the following regression results.

Table 2. Estimates of Factors Affecting Competitiveness of Indonesian CPO Exports in the Global Market

\begin{tabular}{ccccc}
\hline \multicolumn{1}{c}{ Variable } & Coefficient & Std. Error & t-Statistic & Prob. \\
\hline C & 9.323721 & 3.975118 & 2.345521 & 0.0332 \\
X1 & 1.249339 & 0.389164 & 3.210319 & 0.0058 \\
X3 & 0.070555 & 0.040711 & 1.733071 & 0.1036 \\
X5 & -1.134124 & 0.276609 & -4.100096 & 0.0009 \\
X7 & -2.458639 & 0.679765 & -3.616896 & 0.0025 \\
\hline R-squared & 0.594493 & & & \\
Adjusted R-squared & 0.486358 & & & \\
S.E. of regression & 0.273173 & & & \\
Sum squared resid & 1.119351 & & & \\
Log likelihood & 0.451060 & & & \\
F-statistic & 5.497693 & & & \\
Prob(F-statistic) & 0.006267 & & & \\
Mean dependent var & 0.009115 & & & \\
S.D. dependent var & 0.381160 & & & \\
Akaike info criterion & 0.454894 & & & \\
Schwarz criterion & 0.703827 & & & \\
Hannan-Quinn criter. & 0.503488 & & & \\
Durbin-Watson stat & 1.861582 & & & \\
Source: Processed Results using Eviews9 & & & \\
\hline
\end{tabular}


Based on the results above, the competitive competitiveness of Indonesian CPO exports in the global market can be shown as follows:

$\mathrm{ECI}=9.323721+1.249339 \mathrm{X}_{1}+0.070555 \mathrm{X}_{3}-1.134124 \mathrm{X}_{5}-2.458639 \mathrm{X}_{7}$

The results showed a determinant coefficient $\left(\mathrm{R}_{2}\right)$ value of 0.59 , meaning that the variation of the independent variables namely Indonesian palm oil plantation area, the export volume of a competing country (Malaysia), soybean oil prices and the exchange rate were only able to clarify the dependent variable, namely the competitiveness of Indonesian CPO export in the global market by $59 \%$ while the remaining $41 \%$ is clarified by other factors outside the model.

Factors that affect the competitiveness of Indonesian CPO export in the global market can be simultaneously shown by using the F test. The results showed a value of 4.50 greater than the Ftable $\alpha=0.05$ (3.01) or $F_{\text {hit }}(4.50)>F_{\text {table }}$ (3.01) with a probability of 0.013745 . This means that the independent variables, namely Indonesian palm oil plantation area, export volume of a competing country (Malaysia), soybean oil prices and the exchange rate affect the dependent variable, namely the competitiveness of Indonesian $\mathrm{CPO}$ export in the global market competitively $\left(\mathrm{R}^{2}>0\right)$.

Factors partially affecting the competitiveness of Indonesian $\mathrm{CPO}$ export in the global market can be determined by observing the probability value of each export competitiveness variable. A probability value smaller than alpha (0.05) show different results at a $95 \%$ confidence level. Based on the results of the above analysis, it can be stated that the Indonesian palm oil plantation area, soybean oil prices and the exchange rate have a real partial impact on the competitiveness of the Indonesian CPO export in the global market while the export volume of Malaysia do not. Details of Indonesian palm oil plantation area $\left(\mathrm{X}_{1}\right)$, the export volume of Malaysia $\left(\mathrm{X}_{3}\right)$, soybean oil prices $\left(\mathrm{X}_{5}\right)$ and the exchange rate $\left(\mathrm{X}_{7}\right)$, can be seen in a competitive manner through the interpretation or description as follows:

\subsubsection{Effects of Indonesian Palm Oil Plantation Area $\left(X_{1}\right)$ on the Competitive Indonesian CPO Export Competitiveness in Global Markets}

Based on the results of the multiple linear regression test, it can be determined that the oil palm plantation area $\left(\mathrm{X}_{1}\right)$ has a coefficient of 1.249339 with a probability of 0.0058 . This means that the Indonesian palm oil plantation area has a real positive value of $5 \%$ level towards the competitiveness of Indonesian CPO export competitively, in which each increase in palm oil plantation area of 1 ha will increase the competitiveness of Indonesian CPO export in the global market by 1.249339 , assuming other factors are considered fixed (ceteris paribus).

This research is supported by a previous research conducted by [13] on the influence of land area, the US dollar exchange rate, wholesale price index of trade on Indonesian tea exports in 
2000-2015. The results showed a positive variable coefficient of land area, which means that efficient use of agricultural land for production increases the value of Indonesian tea export.

\subsubsection{Effects of the Export Volume of Competing Countries (Malaysia)( $\left.\mathrm{X}_{3}\right)$ on the Competitive Indonesian CPO Export Competitiveness in the Global Market}

The results show that the Malaysian CPO volume regression coefficient is 0.070555 with a margin of error of 0.1036 . This means that changes in the volume of Malaysian CPO export do not significantly affect the competitiveness of Indonesian CPO export, for 0.1036 is greater than alpha (0.05) or a confidence interval of up to $95 \%$. The absence of a real impact in the volume of Malaysian CPO exports on the competitive Indonesian CPO export competitiveness in the

global market may be caused by the greater volume of Indonesian CPO export compared to the increase in Malaysian CPO export volume.

The results are supported by a previous study conducted by [14] on performance comparisons of Indonesian and Malaysian oil palm plantations. This study shows that the planting and harvest area of Indonesian oil palm plantations are higher than that of Malaysia, CPO production of oil palm plantations in Indonesia is higher than Malaysia, and on average the development performance of Malaysian domestic CPO consumption is higher than that of Indonesia, while the development performance of Indonesian CPO export are higher than Malaysia.

\subsubsection{Effects of Soybean Oil Prices $\left(X_{5}\right)$ on the Competitive Indonesian CPO Export Competitiveness in the Global Market}

The soybean oil prices (X5) have a coefficient of -1.134124 with a probability of 0.0009 . This means that the price of soybean oil has a negative effect on the competitiveness of Indonesian CPO export in the global market, in which each increase in soybean oil prices by 1 USD will reduce the competitiveness of Indonesian CPO exports on the global market by 1.134124, assuming other factors are considered constant (ceteris paribus).

[12] conducted on analysis of competitiveness and factors affecting Indonesian CPO export to China, Malaysia and Singapore in the ASEAN-China Free Trade Agreement scheme. The results from [12] show that the coefficient of the price of soybean oil (PSBO) is -0.22 . The negative coefficient value indicates that an average increase in the price of soybean oil by $1 \%$ will reduce the volume of $\mathrm{CPO}$ exports to China, Malaysia and Singapore by $0.22 \%$ (ceteris paribus).

\subsubsection{Effects of the Exchange Rate $\left(\mathrm{X}_{7}\right)$ on the Competitive Indonesian CPO Export Competitiveness in the Global Market}

The exchange rate $\left(X_{7}\right)$ has a coefficient of -2.458639 with a probability of 0.0025 . This means that the exchange rate has a negative effect on the competitiveness of Indonesian $\mathrm{CPO}$ export in the global market, in which each $1 \%$ increase in the exchange rate will reduce the 
competitiveness of Indonesian CPO export in the global market by $245 \%$, assuming other factors are considered constant (ceteris paribus). This is in line with a previous research conducted by [11] on the analysis of competitiveness and factors affecting Indonesian palm oil export. The results from [11] show that the exchange rate has a significant negative effect on palm oil exports, both in the long and short term.

\section{Conclusion}

From the results of this research, it can be concluded that: (1) Indonesian CPO has comparative competitiveness (RCA) in the global market with an increasing trend from 1998 to 2017, while competitive competitiveness (ECI), although positive, experience an upward trend negative. This is indicated by the average RCA calculation result of 60.93 and the average ECI calculation result of 1.07 and (2) Factors that comparatively affect the competitiveness of Indonesian $\mathrm{CPO}$ export in the global market are domestic CPO production, global CPO prices and petroleum prices while factors that competitively affect the competitiveness of Indonesian CPO export are palm oil plantation area, Malaysian export volume, soybean oil prices and exchange rates. Factors that positively impact Indonesian CPO competitiveness are domestic CPO production, oil prices and the oil palm plantation area. Improving these variables will increase the competitiveness of Indonesian CPO export, while an increase in CPO domestic production, global $\mathrm{CPO}$ prices, soybean oil prices and the exchange rate will reduce the competitiveness of CPO exports. The variable that has no significant effect is the export volume of Malaysia.

\section{REFERENCEES}

[1] T. Tambunan, Perdagangan Internasional dan Neraca Pembayaran: Teori dan Temuan Empiris. Jakarta, LP3ES, 2000.

[2] Badan Pusat Statistik. 2019. PDB Triwulanan Atas Dasar Harga Konstan 2010 Menurut Lapangan Usaha (Miliar Rupiah), 2014-2018. Badan Pusat Statistik. Jakarta. Diunduh dari https://www.bps.go.id. Diakes pada tanggal 8 Februari 2019.

[3] M. Euler, "Oil Palm Expansion among Smallholders Farmers in Sumatra, Indonesia," Journal of Agricultural Economics, vol. 67, no.3, pp.658-676, 2016.

[4] Y. Clough, V. V. Krishna, M. D. Corre, K. Darras, et al, "Land Use Choices Follow Profitability at The Expense of Ecological Functions in Indonesia Smallholders Landscapes," Nature Communication, vol. 7, pp. 13137-13149, 2016.

[5] V.V. Krishna, Differential Livelihood Impacts of Oil Palm Expansion in Indonesia. Agricultural Economics, vol. 48, no. 5, pp. 639-653, 2017.

[6] Pusat Data dan Sistem Informasi Pertanian, Outlook Kelapa Sawit: Komoditas Pertanian Subsektor Perkebunan. Kementerian Pertanian, Jakarta, 2017.

[7] International Trade Center, List of exporters for the selected product Product: 1511 Palm oil and its fractions, whether or not refined (excluding chemically modified), 2019. [Online] www.trademap.org. 
[8] United Nation Commodity Trade. 2018. UNCOMTRADE Database. http://comtrade.un.org diakses pada tanggal 10 November 2018.

[9] Turnip, S. M. Lely, Suharyono, Mawardi, M. Kholid, "Analisis Dayasaing Crude Palm Oil (CPO) Indonesia di Pasar Internasional”, Jurnal Administrasi Bisnis, vol. 39, no.1, pp.185 $-194,2016$.

[10]E. Wulansari, E. Yulianto and E. Pengestuti, "Pengaruh Jumlah Produksi, Harga Internasional, Nilai Tukar dan Tingkat Suu bunga Terhadap Tingkat Daya Saing Ekspor Kelapa Sawit Indonesia”, Jurnal Administrasi Bisnis (JAB), vol. 39, no. 2 Oktober 2016, pp. 177-186, 2016.

[11] Purnamasari and D. Ayu, "Analisis Daya Saing dan Faktor - Faktor yang Mempengaruhi Ekspor Kelapa Sawit Indonesia".Undergraduated Thesis, Economic and Business Faculty, Universitas Muhammadiyah Surakarta, Surakarta.

[12]A. Widyastutik and A Zaenal, "Analisis Daya Saing dan Faktor - Faktor yang Mempengaruhi Ekspor CPO Indonesia ke China, Malaysia, dan Singapura dalam Skema ASEAN-China Free Trade Agreement", Jurnal Manajemen dan Agribisnis, vol. 8, no. 2, pp. 65-73, 2011.

[13] K. A. Suhartawan and W. Sudirman, "Pengaruh Luas Lahan, Kurs Dollar Amerika, Indkes Harga Perdagangan Besar Terhadap Ekspor Teh Indonesia tahun 2000-2015", E-Jurnal EP $U M D$, vol. 7, no. 7, pp. 1472-1500, 2016.

[14] M. Hudori, "Perbandingan Kinerja Perkebunan Kelapa Sawit Indonesia dan Malaysia", Jurnal Citra Widya Edukasi, vol. 9, no. 1, pp. 93-112, 2017. 